\title{
Use of Overlaying Technology in Area of Increasing Ploughshares Service Life
}

Petr Hrabě, Miroslav Müller, Petr Novák

Faculty of Engineering, Czech University of Life Sciences Prague. Czech Republic. E-mail: hrabe@tf.czu.cz, muller@tf.czu.cz,novak@tf.czu.cz.

\begin{abstract}
A soil processing belongs among basic steps in an area of a crop farming. The research was focused on increasing a service life of ploughshares by an overlaying technology. The research within field conditions was focused on innovations of ploughshares in the area of a conventional processing of the soil by means of the overlaying technology. A new functional profile was created by means of overlaying electrodes on the conventional tool in order to respect drainage of the processed soil, i.e. oblique overlays. The overlaying material was put in the most stressed places of the ploughshare, i.e. parallel with a face and an edge and these both in a front as well as in a back part. New functional surface was distinguished for a reinforcement of a top of the ploughshare edge and the back part of the ploughshare. Overlaying material was of carbide type OK Tubrodur 15.82. Within the tools service life testing under the field conditions the change of the tools shape and their mass loss were investigated. Statistical methods were used for evaluating of the experiments.
\end{abstract}

Keywords: soil, abrasive wear, functional surface, overlaying material

\section{Acknowledgement}

This paper has been done when solving the grant IGA TF.

\section{References}

[1] MÜLLER, M., VALÁŠEK, P. (2012). Abrasive wear effect on Polyethylene, Polyamide 6 and polymeric particle composites. In: Manufacturing Technology, Vol. 12, No. 12, pp. 55-59.

[2] PETRÁSEK, S., MÜLLER, M. (2014). Setting of Angle of Soil Flow on Ploughshare at traditional Processing of Soil. In: Manufacturing technology, Vol. 14, No 3, pp. 407-412.

[3] KIM, S., SON, K. J., YANG, Y.S., YARAGADA, P.K.D. (2003). Sensitivity analysis for process parameters in GMA welding processes using a factorial design method. In: International Journal of Machina Tools and Manufacture, Vol. 43, pp. 763-769.

[4] VOTAVA, J., ČERNY, M., FILÍPEK, J. (2007). Abrasive wear of ploughshare blades made of Austempered Ductile Iron. In: Acta Universitatis Agriculturae et Silviculturae Mendelianae Brunensis, Vol. 55, No. 1, pp. 173-182.

[5] LIŠKA, J., FILÍPEK, J. (2012). The resistance of ledeburitic tool steels against the abrasive wear. In: Acta Universitatis Agriculturae et Silviculturae Mendelianae Brunensis, Vol. 60, No. 6, pp. 231-242.

[6] LEGÁT, V., JURČA, V., ALEŠ, Z. (2011). Contribution to plough shares and chisels useful life optimization. In: Scientia Agriculturae Bohemica, Vol. 42, No. 2, pp. 73-78.

[7] NOVÁK, P., MÜLLER, M., HRABĚ, P. (2015). Application of overlaying material on surface of ploughshare for increasing its service life and abrasive wear resistance. In: Agronomy Research, Vol. 13, No. 1, pp. 158-166.

[8] NOVÁK, P., MÜLLER, M., HRABĚ, P. (2014). Research of material and constructional solution in area of conventional soil processing. In: Agronomy Research, Vol. 12, No. 1, pp. 143-150.

[9] KEJVAL, J., MÜLLER, M. (2013). Mechanical properties of multi-component polymeric composite with particles of Al2O3/SiC. In: Scienty Agriculturae Bohemica, Vol. 4, pp. 237-242.

[10]VALÁŠEK, P. (2014). Mechanical properties of epoxy resins filled with waste rubber powder. In: Manufacturing Technology, Vol. 14, No. 4, pp. 632-637.

[11]DOUBEK, P., FILÍPEK, J. (2011). Abrasive and erosive wear of technical materials. In: Acta Universitatis Agriculturae et Silviculturae Mendelianae Brunensis, Vol. 59, No. 3, pp. 13-21.

[12]HRABĚ, P., MÜLLER, M. (2013). Research of overlays influence on ploughshare lifetime. In: Research in Agricultural Engineering, Vol. 59, No. 4, pp. 147-152.

[13]NATIS, A., PETROPOULOS, G., PANDAZARAS, C. (2008). The influence of soil type, soil water and share sharpness of a mouldboard plough on energy consumption, rate of work and tillage quality. In: Journal of Agricultural Engineering Research, Vol. 42, No. 2, pp. 171-176. 